\title{
The influence of party funding on the bank indebtedness of political parties
}

\author{
José Antonio Cavero-Rubio $^{a}$, Mónica González-Morales ${ }^{\mathrm{b}}$ \\ a) Miguel Hernandez University of Elche, Edificio la Galia, Avda. de la Universidad s/n. 03202 Elche-Alicante-Spain. \\ b) Miguel Hernandez University of Elche, Avda. de la Universidad s/n. 03202 Elche-Alicante-Spain.
}

\author{
${ }^{a}$ Corresponding author. \\ E-mail address: cavero@umh.es
}

\section{A R T I C LE I N F O}

Article history:

Received 29 December 2018

Accepted 3 May 2020

Available online 1 July 2021

\section{JEL classification:}

D73

H50

H83

M41

Keywords:

Keywords:
Political parties

Party funding

Bank indebtedness

Agency costs

Spain

\section{A B S T R A C T}

Political parties are private organizations that perform public functions and, as such, they are the mechanisms for representing the interests and ideologies of citizens. In order to fulfil this role, they receive both public and private funding. However, since the financing they obtain is insufficient to cover their excessive expenses, it has become common practice for them to resort to loans with credit institutions, resulting in a high bank indebtedness. In this respect, since bank indebtedness can hinder the equal opportunities of political parties, limit their independence and generate agency costs, the aim of this study is to analyse the relationship between the different funding sources of political parties and their bank indebtedness. In addition, a series of aspects have been taken into account that may condition the variables studied and their relationship, such as the current political finance regulation, the geographical scope of the political party, its size and having governed the country. To this end, a longitudinal study has been carried out, including an analysis of the financial and accounting statements of the ten Spanish political parties represented in Congress between 2000 and 2013. The results of the panel data technique indicate that the bank indebtedness of political parties is conditioned by both private and public resources. In addition, while size influences bank indebtedness positively, geographical area has a negative effect. Having governed also conditions bank indebtedness, although its sign depends on the source of private funding.

(C)2021 ASEPUC. Published by EDITUM - Universidad de Murcia. This is an open access article under the CC BY-NC-ND license (http://creativecommons.org/licenses/by-nc-nd/4.0/).

\section{Influencia de la financiación de los partidos en el endeudamiento bancario de los partidos políticos}

\author{
R E S U M EN
}

\begin{abstract}
Los partidos políticos son organizaciones privadas que cumplen funciones públicas, al ser mecanismos de representación de los intereses y de las ideologías de la ciudadanía. Para ello, reciben financiación tanto pública como de particulares. Sin embargo, dado que la financiación obtenida es insuficiente para cubrir sus desmedidos gastos, han convertido en práctica habitual recurrir a los préstamos con entidades financieras, asumiendo un elevado endeudamiento bancario. A este respecto, puesto que el endeudamiento bancario puede obstaculizar la igualdad de oportunidades de los partidos políticos, limitar su independencia y generar costes de agencia, el objetivo de este estudio es analizar la relación existente entre las distintas fuentes de financiación de los partidos políticos y su endeudamiento bancario. Adicionalmente se han tenido en cuenta una serie de aspectos que pueden condicionar las variables estudiadas y su relación, como son la normativa vigente en materia de financiación, el ámbito geográfico del partido político, su tamaño y haber gobernado el país. Para ello, se ha realizado un estudio longitudinal donde se han analizado los estados financiero-contables de los diez partidos políticos españoles representados en el Congreso de los Diputados entre 2000 y 2013. A través de la utilización de la técnica de datos de panel, los resultados indican que el endeudamiento bancario de los partidos políticos está condicionado tanto por los recursos privados como los públicos. Además, mientras que el tamaño tiene una influencia positiva sobre el endeudamiento bancario, para el ámbito geográfico es negativa. Haber gobernado también condiciona el endeudamiento bancario, aunque su signo depende de la fuente de financiación privada.
\end{abstract}

C2021 ASEPUC. Publicado por EDITUM - Universidad de Murcia. Este es un artículo Open Access bajo la licencia CC BY-NC-ND (http://creativecommons.org/licenses/by-nc-nd/4.0/). 


\section{Introduction}

Political parties are private organisations with a public mission that require funding to carry out their activities. In order to sustain their ordinary activity and above all to finance election campaigns, political parties need huge sums of money that they are unable to cover with the state subsidies and private income they receive. For this reason, the usual practice is to resort to indebtedness with credit institutions, which has become an important source of funding for these organizations (Ariño, 2009). In this regard, in 2015, according to data extracted from the Court of Auditors (CA) (2015), bank debt represented $70.95 \%$ of the total public-private revenue of political parties. This financial insufficiency has led to a situation of chronic indebtedness in the financial structure of many political formations, leading some of them to a situation of technical bankruptcy with negative net worth (Rodríguez Teruel \& Casal Bértoa, 2016).

Although bank financing is widely used by political parties, dependence on this practice cannot be justified today as it was in the early years of Spanish democracy. In this period, public subsidies were mainly used to finance election campaigns and the activity of parliamentary groups. In addition, after years of prohibition, the lack of social roots of political parties. Both circumstances meant that political parties had serious difficulties in being able to meet current expenses (García Viñuela \& Artés, 2005). However, after the adoption of Organic Law 3/1987 on the Financing of Political Parties (OLFPP 1987), this situation changed. This law regulated the ordinary funding of political parties for the first time and set a 140\% increase in state subsidies for ordinary expenditure (García Viñuela \& González de Aguilar, 2014), which would partly contribute to solving the historical debt that political parties had with credit institutions (Martínez Cousinou, 2013; Maroto, 2018).

Since then, resources from public coffers have become the main source of party funding, and the approval of the current Organic Law 8/2007 on the Financing of Political Parties (OLFPP 2007) would reinforce their financial importance. While on the one hand, this law introduced control and transparency measures, it also entailed an additional restriction on funding from individuals, legal cover for unlimited debt cancellation, and a consolidation of the prevailing state funding regime.

However, despite the fact that these reforms increased public resources for political parties, their economic problems have persisted. The volume of public subsidies resulted in organizations becoming totally dependent on the State and without any incentives to seek funding from individuals. The apparent inability of political parties to involve their voters economically in their ideological project has been compensated with public money and loans from the banking sector. In this respect, according to CA data, political party subsidies experienced significant growth, with an increase of almost 53\% between 1988 and 2009. This increase in subsidies received by political parties was especially remarkable during the decade 2000 and 2009 (29.21\%), since every year political parties saw this item rise and it was not until 2010 that this situation was reversed. In the context of the economic crisis, the parties adopted a policy of reducing their own subsidies, which meant cutting them by $38.27 \%$ between 2009 and 2015. This action was not so much a strategy of economising public budgets, but rather an interest in recovering part of their loss of legitimacy in the eyes of public opinion and voters as a result of corruption (Rodríguez Teruel \& Casal Bértoa, 2018).
The main cause of the bank indebtedness of political parties could be attributed to their need to have the largest amount possible of financial resources to compete in elections. In the same way that the governing parties increase public spending during election years to gain votes and secure re-election, (García Sánchez et al., 2011; Balaguer \& Brun, 2013), political parties have assumed that the greater the electoral expenditure, the greater the number of votes. Consequently, in order to guarantee greater representation, they incur excessive electoral expenses. It is a perverse system where political parties imitate the behaviour of their adversaries. When a party makes large investments in its electoral campaign, rival parties are forced to also increase their expenditure so they can obtain an electoral benefit (PintoDuschinsky, 2008), which does not necessarily imply an additional benefit for either the parties or society. This imitation behaviour could be explained by the political organisations' interest in achieving the electoral success of others, and avoiding the uncertainty of adopting alternative practices (DiMaggio \& Powell, 1983).

In this sense and as a logical consequence, this imitation effect can also be transferred to the practice of systematically resorting to financial credit in order to be able to execute all the expenses they consider necessary to achieve recognition and social representation. Furthermore, this mimetic behaviour of Spanish political parties can also be favoured by institutional factors such as the existence of a regulation that barely contemplates limitations or sanctions on party overindebtedness, thus contributing to the consolidation of bank indebtedness in political organisations.

Nevertheless, financing through bank indebtedness should be controlled because it can be a distorting factor in the party system and in the country's legislative and economic system. On the one hand, from the point of view of equality of opportunity, if the criteria for access to loans and the conditions of loans are not uniform, bank financing may be an obstacle to political plurality. On the other hand, from the perspective of agency theory, if the behaviour of the agent (political representatives) is conditioned by their financial needs, there is a risk that in their actions the maximisation of their interests prevails, rather than those of the principal (voters). In this regard, it may happen that banks that grant loans and offer below market conditions to political parties could be seeking some kind of benefit, such as regulations or political actions that are favourable to them, thereby generating agency costs of political representation (García Viñuela, 2007).

To reduce these agency losses, control measures and transparency of information can be established, but also other institutional controls. One example is the prohibition of banks from lending money to political parties on below market conditions. Another one is the setting of limits on the bank indebtedness of political parties. It is also possible to intervene in the indebtedness of political parties by controlling their income and expenditure. In any case, as mentioned above, bank debt is a complex issue because of the important political and economic implications it entails and its regulation is also complex. Thus, it is relevant and useful to study the factors that may condition it, by carrying out an analysis that may serve as a reference to the legislator, the citizens, the CA and the financial managers of the parties, for the establishment of appropriate measures that would control the bank debt of political parties. However, so far the literature on the finances of Spanish political parties has mainly dealt with analysing and discussing the financing model of parties (Van Biezen, 2000; Nassmacher, 2001; Argandoña, 2001; Holgado, 2003; García Viñuela \& Artés, 2005; Ariño, 2009; 
Sánchez Muñoz, 2013, 2015; García Viñuela \& González de Aguilar, 2014) and in some cases describing their level of bank indebtedness (Nassmacher, 2001; Argandoña, 2001; Holgado, 2003; García Viñuela \& Artés, 2005; Ariño, 2009; Sánchez Muñoz, 2013, 2015; García Viñuela \& González de Aguilar, 2014). On the other hand, some empirical studies have also analysed the solvency of Spanish parties, concluding that they have a high risk of insolvency (Rodríguez López, 2011). Yet, to date, no attention has been paid to the factors that affect the high dependence of political parties on credit institutions. Hence, the purpose of this study is to fill a gap in previous research by addressing the effect that political party funding sources have on their volume of bank debt.

Thus, the aim of this study is to analyse whether there is a relationship between the different funding sources for the ordinary activity of political parties -public (subsidies) and private (membership fees, contributions from public posts, donations and bank loans)- and the level of bank indebtedness of political parties. And, since the effects of this relationship can be significantly different depending on the characteristics of a political party and the current funding regulations, four control variables have been introduced: the applicable law regulating the different sources of funding for political parties and the possibility of indebtedness; size; geographical scope; and having governed the country.

In order to achieve this objective, a longitudinal study has been carried out, including an analysis of the financial and accounting statements from the CA of the ten Spanish political parties represented in the Congress of Deputies for the period between 2000 and 2013. The results of the panel data technique indicate that the bank indebtedness of political parties is particularly conditioned by both the private and public resources they obtain. However, while public subsidies have a negative impact because the greater this revenue is, the lower bank indebtedness will be, private resources, excepting membership fees, contribute to increasing the dependence of political parties on banks. The size of the party also influences bank indebtedness significantly, since the larger the party, the lower its bank indebtedness rates. On the other hand, although there is no statistically significant relationship between the financing law and bank indebtedness, the geographical scope is evidently a conditioning factor that makes state level parties resort more to bank debt. Likewise, special attention should be given to the influence that having governed the country has. Unlike the parties that have not governed, for those that have, recourse to bank credit is subject to other additional conditioning factors linked to private funding.

The timeliness and relevance of this study lies in the fact that it identifies factors that condition the bank indebtedness of political parties and establishes the effect they have on this financial indicator. Therefore, these findings may contribute to new reflections which can broaden the debate on the regulation of the public and private funding of political associations. It is therefore considered that this research may be useful for political parties. Awareness of the relationship between funding sources and bank indebtedness can help them to design a more optimal financial structure by balancing the different funding sources. Similarly, knowing how different quantitative and qualitative factors affect the dependence of credit institutions on political parties will provide the legislator with complementary information to reconsider existing regulations. In this way preventive and corrective measures could be adopted to deal with the high level of bank indebtedness of political parties and thus mitigate their possible adverse effects. On a research level, the per- spective of this study opens up the possibilities for the development of a future line of research. Finally, citizens will have information about how political parties are financed, as well as their level of indebtedness, allowing them to exercise a legitimate social control over political parties.

The rest of the paper continues with a general overview of the funding system of Spanish political parties, which deals with a review of the legal framework that regulates party funding for ordinary activities and its evolution. In addition, the problems derived from bank indebtedness are raised and the hypothesis to be contrasted is developed. Following this, an outline is given of the sample, variables and methodology used to analyse the data, and the results obtained from the descriptive analysis and those from the application of the panel data technique are presented. Finally, these results are discussed, and the main conclusions are drawn.

\section{Bibliographic review}

\subsection{Financing of political parties: public vs. private}

Economic resources play a fundamental role in the development and sustainability of the political system. Just as democracy cannot be conceived without a diversity of parties, it is unthinkable that political actors can defend and articulate democratic pluralism if they do not have sufficient economic resources. However, there are two decisive factors: the funding model adopted, and the legal regulation of the funding sources permitted by a country to provide political parties with financial resources (Casal Bértoa et al., 2014). Both will affect whether their financial needs can be met, and by extension, their need to resort to bank indebtedness to cover the deficits in their economic resources.

In this sense, the funding model applicable in practically all democratic countries is based on a public-private duality. In this respect, while public funding sources are instrumentalised through subsidies, private sources are mainly provided through donations, contributions from public posts, membership fees and bank loans. This model of political party funding is undoubtedly a controversial issue from a double perspective. Firstly, there is the economic aspect related to the importance of the public resources allocated to these organisations and their possible inefficiencies. And, secondly, there are the political and ethical aspects, related to the need for party funding to be subject to justification, control and inspection before the State and citizens.

Given the public dimension of their functions, there is a general opinion that political parties are legitimised to receive funds from the State. However, many authors question the amounts granted, the allocation system and the effectiveness and efficiency of this type of financing (Argandoña, 2001; García Viñuela \& Artés, 2005; Ariño, 2009; García Viñuela \& González de Aguilar, 2014; Pérez Ugena, 2015).

Among the main reasons given by the doctrine for funding political parties with public money is that of guaranteeing equal opportunities for all political forces. As Sartori (2000) states, in order to implement a democracy, there must be equity in the resources of political parties. However, several authors (Blanco Valdés, 1994, 1995; López Garrido, 1994; Gillespie, 1998; Van Biezen, 2000; García Viñuela \& Artés, 2005; Martínez Cuevas, 2006; Santano, 2016) find that the Spanish regime for the allocation of public funds through subsidies is one of the causes of inequality between political parties. This regime benefits the majority parties and can therefore generate as many inequalities as private funding can (Ariño, 2009). One of the imbalances that public fund- 
ing can entail is evident in the parties' access to bank financing. In fact, it is much more restricted for minority parties because they do not have the credit guarantee of public subsidies (Martínez Cousinou, 2013), and this can constitute a barrier to political pluralism by hindering the emergence of new parties due to a lack of economic resources (Paltiel, 1980; Del Castillo, 1985; Nassmacher, 2001).

However, it must be made clear that an overprotective public funding regime discourages political parties from seeking other revenue sources. It disengages them from civil society and could turn them into "public utility services", thus undermining their private nature and organizational capacity (Van Biezen 2004, 2008). To avoid this, it is necessary to establish mechanisms that contribute to fostering the participation and commitment of civil society in political activity and its funding (Nassmacher, 2003).

In this respect, it should not be forgotten that political parties are associations of a private nature that represent the interests of a more or less large group of citizens. Therefore, they are primarily the ones who should financially sustain them, despite the inequalities that may occur (Del Castillo, 1994; Prpi, 2004). For Ariño (2009), it is a more sensible procedure than the obligation imposed on all voters who, through their taxes, are expected to support political groups that they in fact reject. Nevertheless, in order for citizens to financially support political associations, there must evidently be legislation that does not restrict private funding and does not restrict the capacity of political parties to finance themselves with this type of resource (Pajares, 1998; Ruiz Rico, 2015; Pérez Ugena, 2015).

However, private funding by individuals, especially from donations, is a form of party support that is not exempt from criticism. Although it frees political parties from an excessive dependence on public funds, there is a need to restrict it because it may become a barrier to equal opportunities (Van Biezen, 2003; Zovatto, 2006; Falguera, 2015). In this sense, Sánchez Muñoz (2013) argues that not placing any limit on private funding sources leaves political parties open to the pressures of economic powers. Moreover, it would mean that some parties, taking advantage of their economic superiority, could exert a greater influence on the will of the voters. Both issues, according to the author, imply a distortion of the level playing field that is absolutely necessary in the electoral contest. However, in this respect it should be pointed out that limitations and prohibitions do not put an end to the existence of parties that are much better financed than others. Instead, they could limit the potential of parties that would have the possibility of emerging and growing with private resources, and this would lead to a loss of competition (Johnston, 2005).

In any case, the truth is that neither subsidies nor private contributions and donations from supporters are sufficient to provide the resources necessary to ensure the functioning of political parties. Reality shows that indebtedness through bank credit has become a common and relevant source of funding, which political parties resort to as a means of covering their financial needs (Ariño, 2009; Martínez Cousinou, 2013). Thus, a source of funding, other than that from individuals who sympathise with the ideology of the party, appears in the rules of the game. Nevertheless, bank financing to political parties could have not only business and commercial interests, but also strategic ones. When credit institutions grant financing on preferential terms or ultimately cancel political parties' debts, they may be trying to exert some influence over them, especially if they are governing parties or they are likely to govern in the future.
In this line of thought, several authors agree that concern about this issue should not focus on limiting and prohibiting private funding, but the primary objective must be transparency (Pinto-Duschinsky, 2002; Van Biezen, 2003; García Viñuela \& Artés, 2005; Ariño, 2009; Pérez Ugena, 2015; Rodríguez Teruel \& Casal Bértoa, 2016). The different sources of private funding must be controlled, and the amounts contributed, the identity of the contributors and the relations they maintain with the party should be disclosed. As Argandoña (2001) argues, the fact that citizens support political parties they share similar ideologies with and whose policies they believe will benefit them cannot be considered an immoral act in itself. Even corporate donations and bank loans alone cannot be seen as a distorting element for parties and the political class. On the contrary, they are lawful if they are carried out within a framework of transparency and access to information that makes it possible to monitor and evaluate the conditions and purposes of these funding sources.

In short, there is an unquestionable relationship between the funding sources that political parties receive and their level of bank indebtedness. In this respect, far from solving the problems of economic insufficiency and dependence on bank credit, public subsidies end up becoming addictive for political parties (Casas Zamora, 2008). Some authors even consider them the cause of the problem of bank indebtedness. Thus, García Viñuela and González de Aguilar (2014) argue that as subsidies increase, parties increase expenses and, consequently, never manage to balance their finances. This argument is not only valid for public funding, but also for private funding, where the insufficiency of private resources has the same influence on the bank indebtedness of political parties, forcing them to resort to bank financing.

Consequently, the public nature of the functions of political parties, the high percentage that public funding represents in their resources and the influence of private funding on the distortion of their correct functioning may limit the independence of political parties (Argandoña, 2001). In order to prevent political parties from taking advantage of the power they acquire from public posts to establish corrupt and clientelist practices (Katz \& Mair, 1995; García Viñuela \& Vázquez, 1996; García Viñuela \& González de Aguilar, 2014), they must give up part of their independence in exchange for transparency. Transparency legitimises the State and citizens to control their revenue and expenditure; it has a coercive effect on the ever-present illicit practices and contributes to generating confidence in the political system and politicians (Scarrow, 2006). Control and accountability will reduce suspicions of there being questionable individualistic influences and interest peddling by those individuals and the private groups that finance them (Sánchez Muñoz, 2013).

\subsection{Political finance regulation in Spain}

As pointed out above, party funding needs to be regulated. The State must implement a regulatory regime for funding political parties that ensures equity in the allocation of public funds and private contributions. In addition, transparency of the origin and application of the economic resources obtained must be guaranteed. Political parties should be held accountable so that both the State and citizens can exercise their legitimate right to require them to undergo supervision and control. This will guarantee an efficient use of public resources and eliminate possible corrupt practices by third parties that could condition the decisions of political parties in favour of private interests.

In Spain, after a long period of dictatorship, democracy 
gave rise to the appearance of more than a hundred political parties in a social context characterized by its lack of roots, demobilization and low affiliation. In this context, the financial self-sufficiency of political parties became impossible (Holgado, 2003; Santano, 2016). In order to meet these financial needs and in response to the economic problems of political parties, the State introduced a mixed finance model that introduced public subsidies (Díaz Santana, 1998). However, this regime was clearly inefficient. On the one hand, it was not able to solve the insufficiency of resources, so political parties had to resort to bank financing, accumulating a substantial debt with credit institutions. On the other hand, the scarce supervision and control of public subsidies and private contributions led to scandals about the illicit funding of some parties. The immediate and inevitable consequence of this situation was the development of a legislative reform that tried to solve these problems (Díaz Santana, 1998, Maroto, 2012; Martínez Cousinou, 2013).

This regulation reform culminated in the approval of Organic Law 5/1985 on the General Electoral Regime (OLGER), which regulated electoral processes and their funding; and two years later the approval of Organic Law 3/1987, on the Financing of Political Parties, which established the rules that regulated ordinary and annual funding. Thus, from 1987 onwards, the State assumed a significant role in the funding of ordinary activities. The OLFPP 1987 increased the budget line for subsidising current expenditure by more than $140 \%$ with respect to 1986 and moved towards a funding regime with an absolute predominance of public funding (García Viñuela \& Artés, 2005). The aim of this law was to increase public funding in order to improve the economic situation of parties that were beset by bank debts and to reduce the need for parties to resort to non-transparent funding sources.

However, as Martínez Cousinou (2013) points out, contrary to expectations, the increase in subsidies meant that political parties had to increase bank loan amounts to cover the disproportionate increase in their expenses. The justification for this is that the parties expected to pay off the loans once they received their subsidies. In this respect, according to CA data for the period the law was in force, the debt of the political parties analysed in this study experienced an average increase of $52.95 \%$. In the absence of limitation on indebtedness, the consequence of OLFPP 1987 was a chronic bank indebtedness problem. As acknowledged by Blanco Valdés (1995) and Holgado (2003), public funding became an additive rather than a substitute for private funding.

Furthermore, in order to avoid the influence of private interests on political activity, the OLFPP 1987 limited the possibility of receiving funding from private resources. However, the lack of effectiveness of control mechanisms made these limitations easily circumvented (Ariño, 2009; Martínez Cousinou, 2013), and therefore it was impossible to prevent illicit funding practices through relations based on spurious interests between donors and political parties. In short, it could be said that the legacy left by the OLFPP 1987 was the numerous cases of corruption that occurred during the 1990s and the early years of the 21 st century.

Thus, corruption, economic insufficiency and bank indebtedness continued to be the endemic evils of political parties, which would lead to the 2007 reform approved by the current Organic Law 8/2007 on the Financing of Political Parties. A law that introduced new measures of control and transparency over party funding, but at the same time reflected the regulator's willingness to establish legislation favourable to their interests (Pérez Francesch, 2009; García Viñuela \& González de Aguilar, 2011).
It was a law that improved the transparency and supervision of private party funding, prohibiting anonymous donations because they were difficult to control. The ultimate aim of this measure was to prevent corporate power groups from using their economic capacity and anonymity to exert any influence on political decisions. However, the OLFPP 2007 did not totally eliminate corporate influence, since it still considered nominative donations from legal entities as a lawful form of financing. Furthermore, taking into account the economic interests of the parties, it extended the limit on all nominative donations from 60,000 euros to 100,000 euros per person per year, excepting donations in kind consisting of real estate of up to any value. Similarly, in order to encourage small contributions, it established tax deductibility on membership fees and contributions not exceeding 600 euros per year.

In order to counteract the economic damage caused by the ban on anonymous donations, there was a $20 \%$ increase in state subsidies for the ordinary activity of political parties. In addition, the OLFPP 2007 included a new source of public funding, consisting of financial aid from Autonomous Communities and Local Corporations. However, it should be noted that even though it was not authorised, parties had already been receiving financial aid from some these administrations in the past, which meant that it would not, in all cases, really generate additional income.

In line with its aim to support party finances and specifically to solve debt problems, the OLFPP 2007 also provided legal coverage for debt renegotiation agreements with belowmarket conditions. This legitimized the controversial cancellations of debts, which had no quantitative limit and the sole requirement of informing the CA and the Bank of Spain. It also eliminated the ban on using more than $25 \%$ of public subsidies for ordinary expenses to make loan repayments. Although loan forgiveness and debt repayment could be seen as a way of reducing the indebtedness of political parties, according to Ariño (2009), it provided the appropriate mechanisms for unlimited recourse to it, because in the event that repayment could not be met, it would always be possible to reach advantageous agreements with credit institutions.

On the other hand, the OLFPP 2007 forced political parties to take a step forward in allowing citizens and the State to exercise their legitimate right to audit and control party accounts. The new regulations introduced new accounting requirements and stipulated that the CA should draw up a specific accounting plan for political organisations. In this regard, although practically all parties began to apply it voluntarily from 2014 until 2019, after it was modified to be brought in line with the Organic Law 3/2015, it was not mandatory. In addition, the new regulation was a significant step forward in transparency and the fight against corruption. It gave the CA new sanctioning powers and authorized it to supervise donations received by party think-tanks and associations linked to political parties, which until then had been beyond the control of the law. However, the regulation of these donations was very permissive and lax. On the one hand, because the quantitative limits of nominative donations to party think-tanks were extended to 150,000 euros. And, on the other hand, because it allowed them to receive donations from companies that held contracts with public administrations, which, in the case of political parties, was prohibited. In practice, it meant that, by using this legal vacuum, parties could be financed through their think-tanks with money from the very same companies they had awarded public contracts.

In 2012, in response to the country's deep economic crisis 
and the scandals about illegal party funding, the Organic Law $5 / 2012$ made the first reform to the OLFPP 2007. One of the main objectives of the new legislation was to tighten conditions for access to private funding. The most significant of these reforms were a $20 \%$ reduction in public subsidies with respect to the previous year and an increase in the number of subjects who could not finance political parties. However, funding was allowed for their think-tanks, including companies that held contracts with the administrations as well as the companies belonging to the same group, those in which they had a majority shareholding and their foundations. New regulations were also introduced for debt forgiveness; they continued to allow total or partial debt forgiveness by credit institutions but prohibited those that exceeded 100,000 euros. However, as recognised by Santano (2016), the law did not clarify whether the limit was per credit institution or per total amount of debt cancellations of a political party over a year.

The new control and supervision mechanisms reinforced the CA's powers to impose sanctions on political parties and party think-tanks that did not comply with the law, and to oversee the contributions received by party think-tanks and related associations. As a measure to promote transparency and information, it included the obligation for political parties and their think-tanks to make their annual accounts public through their websites once they had been audited by the CA.

Advances in control and transparency were made in 2015 with respect to the second and last reform of the OLFPP 2007 through the approval of Organic Law 3/2015. This is a legislative reform, like the previous ones, aimed at fighting corruption and considered the most ambitious in terms of party control and transparency (Sánchez Muñoz, 2015; Jiménez \& Villoria, 2018). Among the most noteworthy measures are the new provisions to prevent the undue influence of private capital on political activity. These measures prohibited donations from companies to political parties, limited donations from individuals to 50,000 euros per person per year and made it mandatory to notify the CA of all donations over 25,000 euros and to identify the donor. It also developed and improved the sanctions regime and made advances in the control and transparency of the economic-financial information of political parties. The information requirements that the financial statements must contain were extended, the figure of the person responsible for the economic-financial management of the party was regulated, and the consolidated annual accounts were extended to local level. This last aspect is especially relevant for the control of illegal funding because, as García Viñuela and González de Aguilar (2014) points out, this financing is most prevalent at local level, especially in areas such as public contracts or urban planning operations.

However, although there have been important advances in the control and transparency of political parties, in the approval of the OLFPP 2007 and its subsequent reforms, legislators wasted the opportunity to introduce significant changes in funding. In contrast to the previous reforms, they did not establish a limitation on public funding or bank indebtedness, or any criterion of proportionality between this types of financing and private funding. On the contrary, the reform has continued to promote a funding regime based on the predominance of public subsidies, reinforcing its hegemony over private funding for which new limitations were established (Núñez, 2009; Pérez Francesch, 2009). However, despite the increase in public funding the excessive credit dependence has not been eliminated, neither has the high level of bank indebtedness (Sánchez Muñoz, 2015), which was only reduced by $6.45 \%$ between 2007 and 2015, the year the last audit report was presented by the CA.

\subsection{Bank indebtedness and its need for control}

On the basis of the above, economic resources play a determining role in the activity of political parties and far from moderating the economic needs of these organizations, they have increased them (Blanco Valdés, 1995; Van Biezen, 2003; Ariño, 2009; Maroto et al., 2013). The data on which this statement is based are shown in Table 1, where it can be seen that the aggregate debt with credit institutions of the ten main Spanish political parties with parliamentary representation has experienced significant growth between 2000 (125,133,881 million euros) and 2013 (180,222,024 million euros), reaching an increase of more than $44 \%$ in 13 years.

Among the reasons that have led to this situation is the need to maintain the parties' complex and bloated bureaucracy and their capacity to cope with a permanent electoral campaign (García Viñuela, 2009; Rodríguez López, 2011). These circumstances have led them to systematically resort to bank credit; either as a means of obtaining liquidity until subsidies are received, or as a means of funding their revenue shortfall.

Evidently, not all parties in the Parlamient have the same relationship with bank credit and, as shown Table 1, the growth of this type of debt in some parties is quite moderate, and in some others it even decreases. Nevertheless, in general terms, bank loans are an important funding source for political parties, generally giving rise to organisations with an excessive dependence on credit institutions and serious problems in dealing with debt repayment. This has even occurred with those parties who have received greater subsidies because of their electoral results. However, overexposure to bank debt is not only an internal problem for political parties, it also puts them in a weak situation vis-à-vis credit institutions, which can imply dangerous asymmetries, irregularities and prejudices for both the party system and society as a whole.

Table 1

Debt (in euros) with credit institutions of the ten parties represented in Parliament between 2000-2013

\begin{tabular}{|c|c|c|c|c|c|c|c|c|c|c|c|c|c|c|c|}
\hline & 2000 & 2001 & 2002 & 2003 & 2004 & 2005 & 2006 & 2007 & 2008 & 2009 & 2010 & 2011 & 2012 & 2013 & $\Delta \%$ \\
\hline IU & 11.189 .331 & 9.101 .840 & 8.797 .617 & 14.106 .311 & 15.036 .344 & 14.043 .323 & 15.120 .613 & 15.011 .611 & 14.090 .364 & 15.076 .135 & 14.276 .382 & 17.420 .722 & 15.167 .281 & 14.564 .494 & 30,16 \\
\hline PSOE & 43.526 .552 & 41.859 .302 & 48.043 .584 & 63.219 .372 & 62.717.137 & 51.616 .160 & 45.901 .866 & 59.937 .433 & 67.706 .069 & 71.516.758 & 56.853 .117 & 70.101 .939 & 71.625.187 & 64.547 .422 & 48,29 \\
\hline PP & 12.032 .022 & 8.381 .955 & 6.485 .185 & 31.189 .850 & 28.359 .450 & 16.324 .240 & 55.718 .558 & 59.937 .803 & 59.527 .038 & 63.662 .694 & 54.259 .417 & 77.991 .930 & 54.302 .680 & 40.546 .262 & 236,99 \\
\hline $\mathrm{CDC}$ & 10.608 .302 & 9.505 .670 & 7.686 .755 & 8.718 .308 & 8.317 .953 & 10.608 .302 & 9.505 .670 & 7.686 .755 & 3.158 .306 & 2.551 .323 & 2.027 .607 & 3.607 .972 & 3.559 .126 & 4.496 .632 & $-57,61$ \\
\hline BNG & 1.037 .914 & 1.493 .988 & 878.072 & 1.672 .114 & 2.139 .012 & 3.300 .111 & 2.497 .245 & 3.643 .219 & 3.043 .469 & 4.329 .687 & 3.724 .494 & 4.709 .902 & 4.299 .894 & 3.241 .852 & $212, .34$ \\
\hline UDC & 4.350 .186 & 4.775 .496 & 4.410 .889 & 3.882 .430 & 4.719 .523 & 5.021 .027 & 8.990 .602 & 12.201 .746 & 12.200 .647 & 13.602 .518 & 14.110 .547 & 16.336 .535 & 16.720 .386 & 17.164.395 & 294,57 \\
\hline PNV & 18.933 .848 & 19.575.379 & 19.830 .040 & 20.630 .669 & 14.018 .855 & 14.269 .904 & 14.702 .683 & 17.161 .455 & 20.065 .664 & 25.953.311 & 28.588 .069 & 27.703.593 & 28.058 .630 & 21.479 .474 & 13,44 \\
\hline PSC & 18.593 .544 & 11.311 .616 & 17.385 .424 & 19.000 .518 & 11.909 .450 & 10.745 .312 & 12.506 .243 & 10.360 .398 & 10.124 .952 & 9.603 .089 & 11.389 .467 & 12.967 .865 & 10.855 .563 & 13.548 .239 & $-27,13$ \\
\hline CC & 217.737 & 0 & 0 & 714.287 & 568.761 & 343.443 & 184.158 & 754.418 & 407.683 & 531.044 & 194.981 & 1.027 .719 & 671.224 & 362.731 & 66,59 \\
\hline ERC & 4.644 .445 & 4.216 .551 & 2.676 .620 & 3.891 .249 & 2.180 .467 & 1.574 .183 & 3.703 .716 & 2.865 .829 & 1.211 .847 & 1.070 .067 & 615.623 & 2.482 .162 & 1.952 .360 & 270.524 & $-94,17$ \\
\hline TOTAL & 125.133 .881 & 110.221 .799 & 116.194 .186 & 167.025 .107 & 149.966 .952 & 127.846 .007 & 168.831 .354 & 189.560 .667 & 191.536.039 & 207.896 .627 & 186.039 .705 & 234.350 .338 & 207.212.331 & 180.222 .024 & 44,02 \\
\hline
\end{tabular}

Source: own elaboration based on CA reports on the audit of the financial statements of the political parties (2000-2013). 
In the first place, this implies that bank loans could be counter to equal opportunities among political forces and cause significant imbalances in the democratic system (Santano, 2016). This is because, although all parties should have access to loans under equal conditions, the truth is that there is no equal treatment on the part of the banking institutions that approve or deny a loan. They apply criteria such as the political representation obtained in previous elections, the expectations of representation predicted by surveys, the relationship with the public powers (Álvarez Conde, 1994, 2005), or simply, as García Cotarelo (1985) points out, criteria of political affinity. In short, mostly subjective criteria that do not guarantee equal treatment of all political parties by financial institutions.

Secondly, bank loans can cause irregularities and distortions in the credit market because they can be used by financial institutions as a means of influencing political decisions. This may be the case, for example, with loans granted by banks to parties on advantageous terms, i.e. at below-market interest rates or debt forgiveness. With respect to the latter, despite efforts to hide this practice, it has historically benefited the majority of Spanish political parties, (Ariño, 2009; Rodríguez Teruel \& Casal Bértoa, 2018; Maroto, 2018). As Coello (2012) acknowledges, it is an act that constitutes a covert donation and therefore a mode of financing that is immoral, to say the least. However, what is most dangerous about it is that it could also be of some benefit to banks, sacrificing public interests and damaging the efficiency of institutions (Ohman, 2013).

In short, dependence on bank credit may produce an alignment of interests between political parties and financial institutions. In this sense, bank indebtedness may be a factor generating agency costs if political representatives, once elected, subordinate the general interest to their own interests and to those of the credit facilitators without the voters, due to problems of information and transparency, being aware of it and therefore, being able to sanction their behaviour at the polls (Lupia, 2003). Also, in the event that these practices were to come to light, the cost of economic inefficiencies would also suffer the additional cost incurred by the corruption phenomena. Costs related to the loss of social legitimacy by political organisations and governments (Rose-Ackerman 1996; Gray and Kaufmann, 1998; Johnston, 1999; Seligson, 2002), the discredit of politics and the degradation of democracy (Tanzi \& Davoodi, 1997).

Consequently, excessive bank indebtedness of political organisations and debt forgiveness practices are a major problem. This has been recognised by the Group of States against Corruption (GRECO), who urge the Spanish authorities to adopt measures to solve it. In its Evaluation Report on Transparency in the Financing of Political Parties in Spain, resulting from the Third Evaluation Round (GRECO, 2009), this Council of Europe anti-corruption body expressed its concern about the over-indebtedness of certain political groups, which left political parties vulnerable to credit institutions. It warned that bank loans could be used to finance political parties through covert donations that were above the thresholds allowed for private donations, thus circumventing funding regulations.

As a result of the recommendations by GRECO and following new warnings from this international body (GRECO, 2011, 2013), the total or partial cancellation of debts by credit institutions was prohibited in 2015, thus eliminating the possibility of parties receiving donations from credit institutions. However, as Maroto (2017) points out, quoting an observation from the CA, this measure is easily circum- vented by banks simply claiming a debt that is overdue and not settled indefinitely. Thus, it is still necessary to implement new reforms aimed at a greater regulation of loans and the possible bank indebtedness of parties because, in general, bank over-indebtedness continues to be a problem for political parties. As recognized by GRECO (2015) in its last Compliance Report, this could lead to risks for democracy and for the economy as a whole. But in order to address the type of measures that must be implemented to reduce over-indebtedness and its potential risks, it is necessary to be aware of the factors that affect the financial insufficiency of Spanish political parties.

At this point, as illustrated in the discussion so far, bank indebtedness can be seen to be conditioned by the different sources of financing that political parties receive. And, according to the arguments developed, the financing sources of political parties could be a determining factor in the bank indebtedness of these organisations. In view of the foregoing, the following hypothesis is defined:

H1: The indebtedness of political parties is influenced by their various funding sources.

\section{Research Design}

\subsection{Sample}

In order to contrast the hypothesis stated, a longitudinal analysis of the consolidated annual accounts of the political parties represented in the Spanish Parliament for the 14 years between 2000 and 2013 has been carried out: Bloque Nacionalista Galego (BNG), Coalición Canaria (CC), Convergència Democràtica de Catalunya (CDC), Esquerra Republicana de Catalunya (ERC), Izquierda Unida (IU), Partido Nacionalista Vasco (PNV), Partido Popular (PP), Partit dels Socialistes de Catalunya (PSC), Partido Socialista Obrero Español (PSOE) and Unió Democràtica de Catalunya (UDC). These are the political parties that have obtained state subsidies throughout the reference period due to their parliamentary representation. The period chosen, from 2000 to 2013, corresponds to the years when, in the absence of their own accounting regulations, the political parties had drawn up their annual accounts following the rules of the 2007 General Accounting Plan and some aspects of the regulation of sectoral adaptation for non-profit entities. Although the application of the General Accounting Plan Adapted to Political Formations is not mandatory until the 2019 financial year, since 2014 most parties have voluntarily submitted their 2014 and 2015 financial statements to the CA applying this accounting standard.

The accounting data used in the study have been taken from the income statements and consolidated balance sheets of the Court of Auditors reports on the audit of the financial statements of the political parties with parliamentary representation in the Congress of Deputies. The period of 14 years, corresponding to 140 observations, is long enough to reach the proposed objective and also includes several elections. The consolidated financial statements have permitted a proper assessment to be made of the economic and financial situation of each political party as a whole. The information they provide allows for a better and more adequate valuation of the economic and financial situation of the political organization as a whole, since these annual accounts represent the aggregation of the financial statements of the political parties in their different branches. 
However, it should be stressed that the reliability of the annual accounts of political parties as a source of economic information is conditioned by the accounting errors and deficiencies noted by the CA. In order to solve, as far as possible, this inconvenience and make the information reliable and comparable, the different formats of the financial statements presented by the political parties were standardised and restated in accordance with the observations made by the CA for each political party. Among these errors were: the incorrect classification of the different elements of the annual accounts, errors in the short- and long-term distribution of items, incorrectly applied recording and valuation criteria, reciprocal transactions in the consolidated statements and reclassification of accounts. However, certain errors, despite having been pointed out by the CA, could not be quantified and, thus, could not be rectified.

According to Pelizzo (2004), this is an inconvenience shared by all studies that analyse the financing of political parties from their financial statements. However, as supported by the papers cited in this study, this limitation does not invalidate the results achieved. According to Rodríguez López (2011), the information is sufficiently adjusted and adequate in quantitative and qualitative terms for the research carried out. Thus, sharing the view of this author, it is considered that the financial statements included in the audit reports of the CA, once they are restated according to the observations and considerations of the audit body, are adequate for the purpose of this research, although the limitations mentioned should be taken into account in the results.

\subsection{Variables}

Table 2 defines the dependent and independent variables, both continuous and dichotomous, used to contrast the hypothesis stated.

Table 2

Variable Analysed

\begin{tabular}{|c|c|c|}
\hline Variable & Description & Abbreviation \\
\hline Bank debt & $\begin{array}{l}\text { Debts with financial institutions / } \\
\text { (Liabilities + Equity Net Asset). }\end{array}$ & DEBT \\
\hline $\begin{array}{l}\text { Cash inflows from } \\
\text { Membership fees }\end{array}$ & $\begin{array}{l}\text { Income from Membership fees / } \\
\text { total cash inflows }\end{array}$ & MF \\
\hline $\begin{array}{l}\text { Cash inflows from } \\
\text { contributions from } \\
\text { public posts }\end{array}$ & $\begin{array}{l}\text { Income from contributions from } \\
\text { public posts / total cash inflows }\end{array}$ & CPP \\
\hline $\begin{array}{l}\text { Cash inflows from } \\
\text { donations }\end{array}$ & $\begin{array}{l}\text { Income from donations / total cash } \\
\text { inflows }\end{array}$ & $\mathrm{D}$ \\
\hline $\begin{array}{l}\text { Cash inflows from } \\
\text { subsidies }\end{array}$ & $\begin{array}{l}\text { Income from subsidies / total cash } \\
\text { inflows }\end{array}$ & SUB \\
\hline $\begin{array}{l}\text { Net Cash inflows from } \\
\text { bank loans }\end{array}$ & $\begin{array}{l}\text { Net income from bank loans / total } \\
\text { cash inflows }\end{array}$ & NBL \\
\hline Political party size & Logarithm of total asset & SIZE \\
\hline $\begin{array}{l}\text { Law on the Financing of } \\
\text { Political Parties }\end{array}$ & $\begin{array}{l}\text { Law on party financing in force } \\
\text { during the period } \\
\text { Yes: OLFPP 2007: } 1 \\
\text { No: OLFPP 1987: } 0\end{array}$ & OLFPP \\
\hline Government & $\begin{array}{l}\text { The political party rules the country } \\
\text { Yes: } 1 \text {; No: } 0\end{array}$ & GOV \\
\hline Scope & $\begin{array}{l}\text { Political parties whose scope of } \\
\text { action extends over the national or } \\
\text { regional territory } \\
\text { Yes: National scope: } 1 \\
\text { No: Regional scope: } 0\end{array}$ & SCOPE \\
\hline
\end{tabular}

Unlike the studies by Ariño, 2009 and Martínez Cousinou, 2013, which use the absolute value of the debt to measure bank indebtedness, the dependent variable DEBT has been quantified following Brusca and Condor (2001), Palomares and Peset (2015). In this way, the defined ratio is able to solve the disadvantages caused by the existence of negative net assets in the calculation of the bank debt ratio. As regards the explanatory variables, they correspond to the percentage of total cash inflows represented by the cash inflows of the different funding sources of political parties.

Since both the individual characteristics of political parties and the funding regulations in force may influence the relationship between the financial resources obtained and the bank indebtedness of political parties, four control variables have been introduced in the study. This improves and enriches the depth of the study and increases the relevance and scope of the results and conclusions obtained from it. For this purpose, the size of the political organisation measured as the logarithm of total assets has been considered. Apart from this, Table 2 reflects the dichotomous variables that identify the party funding law in force at each moment of the time series, the circumstance that the political party has occupied the national government and the scope of action of the political organisation.

Different control variables have also been included in the study. On the one hand, since the level of bank indebtedness of political parties has been influenced by the current regulatory framework, the study has introduced the differentiation between the two regulations in the period analysed: the OLFPP 1987 and the OLFPP 2007. In this sense, given that each of these regulations established different limitations and prohibitions, one would expect their effect on the level of bank indebtedness to be different. Specifically, the OLFPP 2007 could be expected to exert a negative influence on bank indebtedness, as this law included measures aimed at reducing it.

On the other hand, as previously discussed, the differentiating characteristics of political parties can influence the amounts of bank financing and therefore their bank indebtedness. In this sense, access to bank financing, the conditions granted, as well as debt forgiveness by credit institutions may be asymmetric depending on the characteristics of the political party. In this respect, to take account of their differences, three control variables have been defined: whether the party is national in scope, its size and whether it has occupied the national government.

First, the situation of financial dependence may be influenced by the scope of action of a political party. The financial needs of national parties are greater than those of regional parties, given that they take part in a greater number of elections and have a much more developed organisational structure. In addition, it could be expected that as national parties receive greater amounts in both public and private funding, their circumstances would be more favourable for accessing bank credit, which in turn would increase their level of indebtedness. However, it could also be expected that the higher public and private resources are, the lower the indebtedness should be, but in view of the real results, this option is not contemplated. Therefore, a positive relationship between the national level of a political party and the level of bank indebtedness could be expected.

Secondly, size can also be a determining factor in the indebtedness of political parties. Those parties who are larger obtain loans more easily and on more advantageous conditions because they present a lower risk for lenders (García Cotarelo, 1985). Therefore, the greater the size of a political party, the greater its access to bank financing is, and its bank indebtedness would increase. And, finally, it can be expected that there is a relationship between bank indebtedness and the fact that a political party has governed. Because of the 
benefits that the national government position can provide (Bolleyer, 2009), on the one hand, one could expect an advantageous access to bank financing in better conditions, increasing its bank indebtedness; and on the other hand, one could also expect the opposite effect on bank indebtedness, as it could have greater access to debt forgiveness.

\subsection{Methodology}

In order to contrast the hypothesis stated, the interrelationships of the variables defined through a multivariate analysis using a multiple linear regression have been considered, where the dependent variable is bank indebtedness and the independent variables are the different funding sources. In addition, control variables (SIZE, OLFPP, GOV and SCOPE) have been introduced, as well as the interaction of dichotomous variables with independent variables. Therefore, the regression model defined to contrast the hypothesis is the following:

$$
\begin{aligned}
D E B T_{i t} & =\beta_{0}+\beta_{1} M F_{i t}+\beta_{2} D_{i t}+\beta_{3} C P P_{i t}+\beta_{4} S U B_{i t}+\beta_{5} N B L_{i t} \\
& +\beta_{6} S I Z E_{i t}+\beta_{7} G O V_{i t}+\beta_{8} S C O P E_{i t}+\beta_{9} O L F P P_{i t} \\
& +\beta_{10} G O V^{*} M F_{i t}+\beta_{11} G O V^{*} D_{i t}+\beta_{12} G O V^{*} C P P_{i t} \\
& +\beta_{13} G O V^{*} S U B_{i t}+\beta_{14} G O V^{*} N B L_{i t}+\beta_{15} S C O P E^{*} M F_{i t} \\
& +\beta_{16} S C O P E^{*} D_{i t}+\beta_{17} S C O P E^{*} C P P_{i t}+\beta_{18} S C O P E^{*} S U B_{i t} \\
& +\beta_{19} S C O P E^{*} N B L_{i t}+\beta_{20} O L F P P^{*} M F_{i t}+\beta_{21} O L F P P^{*} D_{i t} \\
& +\beta_{22} O L F P P^{*} C P P_{i t}+\beta_{23} O L F P P^{*} S U B_{i t} \\
& +\beta_{24} O L F P P^{*} N B L_{i t}+\varepsilon_{i t}
\end{aligned}
$$

Where for party $\mathrm{i}$ in year t: DEBT $=$ Debts with credit institutions $_{\text {it }} /$ (Liabilities $_{\text {it }}+$ Equity $_{\text {it }}$ ). MF $=\%$ of total cash inflows membership fees ${ }_{i t}$. CPP $=\%$ total cash inflows contributions from public posts ${ }_{\mathrm{it}}$. $\mathrm{D}=\%$ of total cash inflows donations $_{\text {it }}$ (natural and legal persons). SUB $=\%$ of total cash inflows state subsidies it $_{\text {. NBL }}=\%$ of total cash inflows net bank loans it $_{\text {. }}$ SIZE $=$ Logarithm of total asset $t_{\text {it. }} \mathrm{GOV}=1$ if the party has been in government and 0 if not. SCOPE $=1$ if the party is national and 0 if not. OLFPP $=1$ if the current finance law is the 2007 Finance law and 0 if not.
Given that the population under study comprises a heterogeneous group of political parties in the period between 2000 and 2013, a contrast of the equation proposed in the hypothesis was carried out using a linear regression analysis with panel data. In the panel data model, two approaches (fixed effects and random effects) are considered according to the behavior of individual and temporal effects i. The Hausman test was applied to decide which of the approaches best fitted the behavior of the sample (Hausman, 1978). The results of the test revealed the absence of random effects in the analyzed model, concluding that the model indicated was fixed effects. Following the extant literature, we also used a fixed effects model for our study (Hausman \& McFadden, 1984; Greene, 1998). For the effects of unobservable heterogeneity corresponding to the specific characteristics of each political party and period, a dummy variable i was introduced for political party and year.

As the dependent variable DEBT and the independent MF and $\mathrm{D}$ have an asymmetric distribution, they have been normalized by root functions (Sakia, 1992). Following Tukey (1977), the optimal transformations used to comply with the hypothesis of normality were the ninth root of DEBT, the square root of CA and the fourth root of D. Subsequently, although the sense of effect does not change, it is necessary to undo the transformations to find out the quantitative effect of the variables on indebtedness.

To measure the intensity of association between the model's variables, Pearson's correlation analysis was carried out. According to Gujarati (2004), as shown in Table 3, there are variables that could give rise to a multicollinearity problem because their correlation coefficient is greater than 0.8 . However, as shown in Table 8, these variables do not appear in the regression model. In addition, since the variance incre-

\begin{tabular}{|c|c|c|c|c|c|c|c|c|c|c|c|c|c|c|c|c|c|c|c|c|c|}
\hline Variables & DEBT & MF & $\mathrm{D}$ & CPP & SUB & NBL & $\begin{array}{c}\text { OLFPP } \\
{ }^{*} \mathrm{MF}\end{array}$ & $\begin{array}{c}\text { OLFPP } \\
{ }^{*} \mathrm{D}\end{array}$ & $\begin{array}{c}\text { OLFPP } \\
{ }^{*} \mathrm{CPP}\end{array}$ & $\begin{array}{c}\text { OLFPP } \\
* \text { SUB }\end{array}$ & $\begin{array}{l}\text { OLFPP } \\
{ }^{*} \mathrm{NBL}\end{array}$ & $\begin{array}{c}\text { SCOPE } \\
{ }^{*} \mathrm{MF}\end{array}$ & $\begin{array}{c}\text { SCOPE } \\
\text { *D }\end{array}$ & $\begin{array}{c}\text { SCOPE } \\
{ }^{*} \mathrm{CPP}\end{array}$ & $\begin{array}{c}\text { SCOPE } \\
\text { "SUB }\end{array}$ & $\begin{array}{l}\text { SCOPE } \\
\text { *NBL }\end{array}$ & $\begin{array}{l}\text { GOV } \\
{ }^{*} \mathrm{MF}\end{array}$ & $\begin{array}{c}\mathrm{GOV} \\
* \mathrm{D}\end{array}$ & $\begin{array}{l}\text { GOV } \\
{ }^{*} \mathrm{CPP} \\
\end{array}$ & $\begin{array}{l}\text { GOV } \\
* \text { SUB } \\
\end{array}$ & $\begin{array}{l}\text { GOV } \\
* \text { NBL }\end{array}$ \\
\hline DEBT & 1 & & & & & & & & & & & & & & & & & & & & \\
\hline MF & 0,043 & 1 & & & & & & & & & & & & & & & & & & & \\
\hline $\mathrm{D}$ & 0,081 & 0,108 & 1 & & & & & & & & & & & & & & & & & & \\
\hline CPP &,$- 245^{*}$ & 0,049 & $-0,162$ & 1 & & & & & & & & & & & & & & & & & \\
\hline SUB & $-0,136$ & $-0,104$ &,$- 432^{* *}$ & ,219* & 1 & & & & & & & & & & & & & & & & \\
\hline NBL & 0,140 &,$- 321^{* *}$ & 0,159 &,$- 208^{*}$ &,$- 677^{* *}$ & 1 & & & & & & & & & & & & & & & \\
\hline OLFPP*MF & $-0,108$ &, $272^{* *}$ & $-0,162$ & $-0,034$ & - 0,144 &,$- 194^{*}$ & 1 & & & & & & & & & & & & & & \\
\hline OLFPP*D & $-0,022$ & 0,129 & 0,076 & $-0,024$ & $-0,043$ & 0,042 & $2,878^{* * *}$ & 1 & & & & & & & & & & & & & \\
\hline OLFPP $* \mathrm{CPP}$ & $-0,138$ & $-0,178$ & $-0,172$ &, $448^{* *}$ & 0,062 & 0,009 & , $686^{* *}$ &, $715^{* *}$ & 1 & & & & & & & & & & & & \\
\hline OLFPP*SUB & $-0,137$ & $-0,030$ &,$- 264^{* *}$ & 0,052 &, $285^{* *}$ &,$- 232^{* * *}$ &, $864^{* * *}$ &, $780^{* *}$ & , $761^{* *}$ & * 1 & & & & & & & & & & & \\
\hline OLFPP*NBL & ,177* &,$- 216^{*}$ & 0,118 & $-0,026$ &,$- 482^{* *}$ & , $690^{* * *}$ &,$- 240^{* * *}$ & 0,131 & 0,081 & $1-, 260$ *** & * 1 & & & & & & & & & & \\
\hline SCOPE*MF & 0,089 & $-0,037$ &,$- 196^{*}$ &,$- 235^{*}$ & $299^{* * *}$ & $-0,106$ & $-0,003$ & 0,008 & $-0,062$ & 20,050 & $-0,094$ & 1 & & & & & & & & & \\
\hline SCOPE*D & 0,041 & $-0,058$ & $-0,113$ &,$- 274^{* * *}$ &, $285^{* *}$ & $-0,098$ & $-0,012$ & 0,021 & $-0,056$ & 0,036 & $5-0,088$ & ,958** & 1 & & & & & & & & \\
\hline SCOPE ${ }^{*} \mathrm{CPP}$ & 0,092 & $-0,119$ &,$- 313^{* *}$ & 0,064 &, $307^{* *}$ & $-0,168$ & 3),018 & 0,041 & 0,144 & 0,134 & $4-0,155$ &, $807^{* * *}$ & *, $731^{* * *}$ & 1 & & & & & & & \\
\hline SCOPE*SUB & 0,146 & $-0,137$ &,$- 255^{* *}$ &,$- 218^{*}$ &, $378^{* *}$ &,$- 177^{*}$ & 0,005 & 0,017 & $-0,008$ & $8 \quad 0,139$ & $-0,143$ & $3,941^{* * *}$ & , $926^{* * *}$ &, $844^{* *}$ & 1 & & & & & & \\
\hline SCOPE*NBL & 0,027 & $-0,055$ & $-0,033$ & $-0,156$ &,$- 322^{* *}$ &, $459^{* *}$ & $-0,067$ & $-0,065$ & $-0,129$ & $-0,152$ & $2,239^{\text {*** }}$ & $-0,084$ & $-0,074$ &,$- 259^{* *}$ &,$- 235^{* *}$ & * 1 & & & & & \\
\hline $\mathrm{GOV} * \mathrm{MF}$ & $-0,132$ & 0,026 & 0,001 & $-0,148$ & 0,147 & $-0,081$ & 0,028 & 0,048 & 0,027 & $7 \quad 0,036$ & $-0,072$ & $2,557^{* * *}$ & , $599^{* * *}$ &, $422^{* *}$ &, $487^{* *}$ & $-0,100$ & 1 & & & & \\
\hline$G O V * D$ & $-0,133$ & 0,022 & 0,009 & $-0,163$ & 0,147 & $-0,079$ & 0,016 & 0,037 & 0,023 & 0,028 & $-0,079$ &, $552^{* * *}$ &, $604^{* * *}$ &, $401^{* *}$ &, $486^{* *}$ & " $-0,096$ & ,993*** & 1 & & & \\
\hline $\mathrm{GOV} * \mathrm{CPP}$ & $-0,112$ & $-0,026$ & $-0,070$ & 0,089 &, $180^{*}$ & $-0,157$ & $7 \quad 0,089$ & 0,117 & ,190" & 0,166 & $5-, 170^{\prime \prime}$ &, $411^{* * *}$ &, $424^{* * *}$ &, $598^{* *}$ &, $430^{* *}$ &,$- 284^{* *}$ & ,770*** & ,740*** & 1 & & \\
\hline GOV*SUB & $-0,138$ & 0,007 & $-0,013$ & $-0,090$ &, $178^{*}$ & $-0,122$ & 0,034 & $+0,059$ & 0,082 & 20,073 & $-0,124$ & $4,540^{\text {*** }}$ &, $584^{\text {*** }}$ &, $488^{* *}$ &, $504^{* * *}$ & ",$- 191^{*}$ &, $974^{* * *}$ &, $972^{* * *}$ &, $865^{* *}$ & 1 & \\
\hline GOV*NBL & 0,065 & 0,017 & 0,029 & $-0,193$ &,$- 190^{*}$ &, $245^{\text {*** }}$ & $-0,048$ & $-0,073$ &,$- 186^{*}$ & $-0,151$ & , 210" & ${ }^{*}-0,100$ & $-0,103$ &,$- 351^{* *}$ &,$- 203^{*}$ & ", $522^{* * *}$ &,$- 186^{*}$ &,$- 177^{*}$ &,$- 542^{* *}$ &,$- 361^{* * *}$ & 1 \\
\hline
\end{tabular}
ment factors (VIF) and the condition index (untabulated) for the independent variables are lower than 10 and 30, respectively, it can be stated that multicollinearity is not present in the model (Pedhazur, 1997; Kleinbaum et al., 1998; Menard, 2002).

Table 3

Pearson correlation test

* Significance at the $5 \%$ level based on two-sided tests.

** Significance at the $1 \%$ level based on two-sided tests. 


\section{Results}

\subsection{Bank indebtedness and party funding. Descriptive stat- istics}

Based on the accounting information of the political parties, Table 4 shows the number of observations and the calculated mean, median and standard deviation descriptive statistics of the quantitative variables for the set of political parties. Tables 5, 6 and 7 show, respectively, the number of observations and the descriptive statistics for each of the two groups resulting from the three dichotomous variables considered: the period before and after the OLFPP 2007, statelevel or regional-level parties and, finally, parties that have governed or have not governed.

Table 4

Descriptive statistics

\begin{tabular}{lccc}
\hline Variables & \multicolumn{3}{c}{ Pooled sample $\mathrm{n}=140$} \\
\cline { 2 - 4 } & Mean & Median & Std.dev \\
\hline DEBT & 0.961 & 0.650 & 0.800 \\
MF \% & 11.94 & 10.03 & 7.91 \\
CPP \% & 6.73 & 6.00 & 4.13 \\
D \% & 5.06 & 3.18 & 5.62 \\
SUB \% & 73.01 & 74.57 & 25.67 \\
NBL \% & 1.84 & -0.24 & 20.57 \\
\hline
\end{tabular}

Table 5

Descriptive statistics for pre-OLFPP 2007 (0) and post-OLFPP 2007 (1)

\begin{tabular}{lcccccc}
\hline \multirow{2}{*}{ Variables } & \multicolumn{3}{c}{ OLFPP $=0$} & \multicolumn{3}{c}{ OLFPP = 1} \\
& \multicolumn{3}{c}{$\mathrm{N}^{\mathrm{o}}$ observations $=80$} & \multicolumn{3}{c}{$\mathrm{N}^{\mathrm{o}}$ observations $=60$} \\
\cline { 2 - 7 } & Mean & Median & Std.dev & Mean & Median & Std.dev \\
\hline DEBT & 0.960 & 0.744 & 0.670 & 0.965 & 0.556 & 0.939 \\
MF \% & 11.89 & 11.16 & 7.61 & 12.00 & 9.34 & 8.40 \\
CPP \% & 6.58 & 5.61 & 4.13 & 6.94 & 6.29 & 4.18 \\
D \% & 6.07 & 4.25 & 6.20 & 3.56 & 1.40 & 4.26 \\
SUB \% & 72.03 & 72.88 & 26.82 & 74.30 & 76.84 & 24.26 \\
NBL \% & 2.13 & -0.33 & 20.02 & 1.47 & -0.24 & 21.39 \\
\hline
\end{tabular}

Table 6

Descriptive statistics for parties at regional level (0) and parties at national level (1)

\begin{tabular}{lcccccc}
\hline \multirow{2}{*}{ Variables } & \multicolumn{3}{c}{ SCOPE $=0$} & \multicolumn{3}{c}{ SCOPE $=1$} \\
& \multicolumn{2}{c}{ N $^{\circ}$ observations $=98$} & \multicolumn{2}{c}{ No $^{\circ}$ observations $=42$} \\
\cline { 2 - 7 } & Mean & Median & Std.dev & Mean & Median & Std.dev \\
\hline DEBT & 0.945 & 0.609 & 0.854 & 0.996 & 0.662 & 0.684 \\
MF \% & 13.17 & 11.16 & 9.20 & 9.68 & 9.88 & 3.88 \\
CPP \% & 7.52 & 7.00 & 4.44 & 5.37 & 5.59 & 3.14 \\
D \% & 6.59 & 5.73 & 6.35 & 2.32 & 1.41 & 2.13 \\
SUB \% & 67.61 & 65.79 & 27.52 & 85.11 & 85.30 & 15.35 \\
NBL \% & 3.09 & 2.93 & 22.18 & -0.79 & -1.81 & 16.62 \\
\hline
\end{tabular}

As can be seen in Table 4, the data show that the average bank indebtedness of Spanish political parties is close to 1 . This is a very worrying value as it would indicate that bank debts represent practically $100 \%$ of the total assets of political parties. In addition, the average net amount of bank loans in the period does not even reach $2 \%$ of the total cash inflows of the parties. As this is not an excessive figure, it would only confirm that bank over-indebtedness is a chronic problem for political organisations that has dragged on for decades due to the difficulties in coping with the repayment of this debt (Rodríguez Lopez, 2011). The excessive dependence on bank financing has led some parties to a situation of asset imbalance, which makes them present negative net worth. This fact proves the special treatment that both the State and credit institutions give to political
Table 7

Descriptive statistics for parties that have not governed (0) and parties that have governed (1)

\begin{tabular}{|c|c|c|c|c|c|c|}
\hline \multirow[t]{2}{*}{ Variables } & \multicolumn{3}{|c|}{$\begin{array}{c}\text { GOVERNMENT }=0 \\
\mathrm{~N}^{\mathrm{o}} \text { observations }=126\end{array}$} & \multicolumn{3}{|c|}{$\begin{array}{c}\text { GOVERNMENT }=1 \\
\mathrm{~N}^{\mathrm{o}} \text { observations }=14\end{array}$} \\
\hline & Mean & Median & Std.dev & Mean & Median & Std.dev \\
\hline DEBT & 1.016 & 0.725 & 0.831 & 0.521 & 0.538 & 0.125 \\
\hline MF \% & 12.07 & 9.60 & 8.37 & 10.97 & 11.96 & 2.42 \\
\hline CPP \% & 6.94 & 6.13 & 4.16 & 5.39 & 5.58 & 3.82 \\
\hline D \% & 5.37 & 3.46 & 5.92 & 2.92 & 2.90 & 1.48 \\
\hline SUB \% & 71.68 & 72.88 & 26.42 & 84.65 & 86.60 & 13.53 \\
\hline NBL \% & 2.45 & 1.06 & 21.10 & -3.27 & -4.11 & 15.06 \\
\hline
\end{tabular}

parties (Rodríguez López \& Fidalgo, 2011), since this situation would not be permitted under any circumstance, if they were mercantile companies. As Table 5 shows, it is a problem that has persisted since the OLFPP 2007 came into force, and therefore highlights the inefficiency of the legislative reform to solve the problems of financial solvency of political parties.

However, group data from dichotomous variables highlight some important differences. Thus, Table 6 shows that political parties at state level, as opposed to those at regional level, have greater bank indebtedness. This would confirm that these organisations, active throughout the Spanish territory, have additional financial needs. And, unlike the regional parties, although they have repaid (or have been forgiven) more bank credit than they have received, as indicated by the negative value of the NBL variable, they are still more indebted. Nevertheless, Table 7 shows that when parties are differentiated according to whether they have been in government or not; despite having a national presence, the bank debt rate and the value of NBL are ostensibly lower in the parties that have governed.

On the other hand, it is worth highlighting the important disproportion of the different types of income, with public income being the largest, as shown in Table 4. This confirms the dependence of all political parties on public subsidies. Table 5 illustrates how this situation is reinforced after the application of the OLFPP 2007 and as a result public resources gain more importance in the parties' financial structure. However, there are significant differences here as well. If we look at Tables 4, 6 and 7, it can be seen that while the average value of public funding for all political parties is around $74 \%$ of the total cash inflows, in state-owned parties that have been in government it is close to $85 \%$. A fact that would show that since they are political organisations that are present in more territories and obtain more votes, they receive more public subsidies. This reduces their incentives to attract resources from the private sector, weakening their interest in establishing links with civil society (Sánchez Muñoz, 2015; Rodríguez Teruel, 2016).

In this sense, one of the funding sources that experiences a greater decrease in stimuli for raising income from private hands is donations. As can be seen in Table 6 , in national parties, donations barely exceed $2.3 \%$ and, on the other hand, in regional parties the percentage is close to $7 \%$. Table 7 shows a similar difference, although less marked, between the parties that have occupied the government and those that have not, with donations reaching $2.92 \%$ and $5.37 \%$, respectively, of the cash inflows.

In addition to the parties' lack of concern for obtaining private funds, another circumstance is the progressive limitations that the legal system has been imposing on donations. As Table 5 shows, before the approval of the OLFPP 2007 , they represented slightly more than $6 \%$ of the political parties' cash inflows and after the aforementioned law, 
they were reduced to an average of $3.56 \%$. Undoubtedly, the objective of the OLFPP 2007 and its reforms was to combat corruption in political parties (García Viñuela \& González de Aguilar, 2014), and donations, through interested money and especially those protected by anonymity, can be one of the main means of corruption within the political class. Thus, the prohibition of anonymous donations, those from companies and the other quantitative and qualitative limitations that were established for this funding source have meant that revenue from this concept has decreased considerably.

However, this restrictive context after 2007 did not encourage parties to seek resources through other sources of private funding such as membership fees. As can be seen in Table 5, although affiliation fees represent the main private funding source with a percentage close to $12 \%$ of the cash inflows of all parties, this figure, as well as the contributions from public posts, hardly varies between the periods before and after the OLFPP 2007. However, the difference becomes apparent when parties are distinguished by their scope and whether or not they have been in government. Tables 6 and 7 reveal that, in these cases, this channel of private funding, as in the case of donations and contributions from public posts, has higher percentages in the parties at regional level and in those that have not governed. This fact once again highlights the inverse relationship between subsidies and bringing parties closer to citizens.

\subsection{Relationship between funding and bank indebtedness of political parties. A multivariate analysis}

Table 8 shows the result of the multivariate regression for the analysis of the association between indebtedness and independent variables and their interactions with OLFPP, SCOPE and GOV. Applying the stepwise method of SPSS statistical software means including in the model only those variables that best contribute to the regression fit, achieving the highest coefficient of determination. Starting from the initial equation, the statistical software successively and automatically includes/removes one by one the independent variables that, firstly, meet/do not meet the statistical criteria of significance (probability of F, value of F) and tolerance and, secondly, have in absolute terms the partial correlation coefficient with the highest/lowest dependent variable. The elimination of variables stops when there are no variables left that meet the input/output criteria, resulting in the final model shown. As can be seen in Table 8, none of the variables has no statistical significance. The adjusted R2 (0.919) suggests that the model presents a fine goodness-of-fit for the sample data.

As can be seen in Table 8, of the five explanatory variables representing the different sources of financing, only SUB, D and CPP have a statistically significant influence on bank indebtedness. Consequently, the hypothesis would be accepted, and it could be stated that funding sources are related to bank indebtedness. It is worth highlighting the positive relation between variables D (0.057) and CPP (0.361) and the bank indebtedness of the political parties. This would mean that the more the weight of these funding sources increases, the greater the rate of bank indebtedness. In addition, this direct relation also appears when CPP interacts with GOV, which implies that for the parties that occupy the government of the country, the positive effect of this variable on bank indebtedness intensifies $(0.361+0.780=1.141)$.

However, not all revenue sources affect bank indebtedness in the same way. As the results indicate, when considering the SUB variable (-0.113), the impact is the opposite. As
Table 8

Multiple linear regression model

\begin{tabular}{|c|c|}
\hline Variables $^{\mathrm{a}}$ & \\
\hline Intercept & $\begin{array}{r}2.047 \\
(24.837)^{* * * *}\end{array}$ \\
\hline $\mathrm{D}$ & $\begin{array}{r}0.057 \\
(1.964) *\end{array}$ \\
\hline СРP & $\begin{array}{r}0.361 \\
(3.005)^{* * * *}\end{array}$ \\
\hline SUB & $\begin{array}{r}-0.113 \\
(-4.608)^{* * * *}\end{array}$ \\
\hline SIZE & $\begin{array}{r}-0.160 \\
(-12.988)^{* * * *}\end{array}$ \\
\hline SCOPE & $\begin{array}{r}0.163 \\
(10.175)^{* * * *}\end{array}$ \\
\hline GOV*MF & $\begin{array}{r}-0.186 \\
(-3.747)^{* * * *}\end{array}$ \\
\hline GOV*CPP & $\begin{array}{r}0.780 \\
(2.794)^{* * * *}\end{array}$ \\
\hline GOV*NBL & $\begin{array}{r}0.137 \\
(1.856)^{*}\end{array}$ \\
\hline Fixed effect variables & Included \\
\hline $\mathrm{N}$ & 140 \\
\hline Adj. R2 & 0.919 \\
\hline
\end{tabular}

Note: Corrected t-statistics are in parentheses.

Significance ${ }^{*} \mathrm{p}<0.1 ;{ }^{* *} \mathrm{p}<0.05 ;{ }^{* * *} \mathrm{p}<0.01$

subsidies gain weight in a party's financial structure, dependence on bank credit decreases. This finding is contrary to what García Viñuela and González de Aguilar (2014) found, and it would indicate that the political parties that receive a high amount in subsidies cover a higher percentage of expenses than those that receive lower public funding, and so resort to bank financing to a lesser extent. However, in view of the results obtained, the thesis by these authors could be coherent for the first two variables analysed, when finance comes from private sources, as in the case of donations and contributions from public posts.

The explanation for this disparity may lie in the fact that subsidies are by far the most relevant party income, and this would therefore allow them to reduce bank financing needs. In addition, it should also be noted that this public financial aid is often used to cancel the bank loans the parties take out to cover the expenses of electoral campaigns (Holgado, 2003), so it is reasonable for it to negatively influence this type of debt.

On the other hand, the results obtained reflect a constant and significant negative relationship between the SIZE variable (-0.160) and the level of bank indebtedness of political parties. One possible argument would be that organisations with a larger volume of assets could have access to additional resources through asset management. However, this relationship may also be linked to the possibility of obtaining advantages in credit conditions that imply lower financing costs and provide more guarantees

Since there is no interaction between OLPFF 2007 and funding sources, contrary to what was expected, there is no relation between bank indebtedness and the current party finance law. Consequently, the changes introduced in OLFPP 2007 to reduce bank indebtedness cannot be said to have had the desired effect. In short, the absence of these variables in the results points to the fact that the legal regulation in matters of party funding does not affect political parties in their decision to resort to bank indebtedness.

By contrast, the variable SCOPE (0.163) does have a stat- 
istically significant and constant influence on bank indebtedness, and there is a positive relationship between being a national party and the bank indebtedness ratio. This result verifies that, despite receiving more subsidies, political parties at national level require more additional funding than those at regional level (Ariño, 2009). In order to maintain all their headquarters throughout the national territory, bear the costs of maintaining the complex and voluminous bureaucracy of the party (García Viñuela \& González de Aguilar, 2014), and undertake the expenses derived from participating in a greater number of elections, they would need greater economic resources, which would lead them to incur a greater level of bank indebtedness.

Additionally, although there is no statistical evidence relating GOV or MF with bank indebtedness, the interaction GOV*MF (-0.186) does present a significant and negative coefficient. For the parties that occupy the national government, the cash inflows they receive through membership fees negatively affects their indebtedness level. This result can be based on the fact that this type of income, in absolute terms, is greater in the parties that have governed (PP or PSOE) because they are the Spanish political organisations with the greatest number of members.

Similarly, it is noted that NBL is not related to DEBT, but the interaction $\mathrm{GOV}^{*} \mathrm{NBL}(0.137)$ is, with a positive coefficient. Therefore, for parties in government, NBL influences their level of bank indebtedness. However, even if the sign of the interaction coefficient is positive, given that NBL can take a positive or negative sign, the influence on the dependent variable can go in both directions. That is to say, it can turn into an increase or decrease in bank indebtedness. In this respect, in Table 7 , it is particularly noteworthy that, during the study period, the NBL ratio is negative for the parties that have governed, which translates into lower bank debt rates.

In this regard, it should be remembered that a negative net amount in bank loans cannot be explained solely by debt repayment. It can also be attributed to the cancellation of debts, which, until its prohibition in 2015 , the main political parties have frequently incurred with the credit institutions, and which according to the data provided by Ariño (2009) reach millionaire amounts. Thus, although the real figures are unknown because both parties and credit institutions try to hide these types of practices (Sánchez Muñoz, 2013), the result obtained would not allow us to affirm that the political parties that have governed have received favourable treatment from credit institutions.

\section{Discussion and conclusions}

This article has investigated the relationship between the bank indebtedness of Spanish political parties and how their different funding sources, size, the laws that regulate them, and factors such as scope or having governed the country influence this relationship. Bank indebtedness can have important consequences for a political organisation and its behaviour in society. And, although this study is limited to Spain, the results obtained are interesting for any other country, regardless of the electoral system and the financing system they apply. As has already been stated in this article, bank indebtedness can generate problems of inequality between political forces and it can therefore be detrimental to democracy. Nevertheless, in our opinion, it may have an even more dangerous implication in that it can restrict the independence of political parties by serving the interests of the financial sector. Thus, political parties themselves must understand that their bank indebtedness acquires a transcendental role in the public sphere. Not only does it have an impact internally, but it also entails agency costs that lead to significant inefficiencies in a country's economic system, to the extent that policies are articulated in favour of credit facilitators and the general interest is not taken into account.

In this sense, this study, in line with the conclusions of Rodríguez López (2011), has noted the excessive financial dependence Spanish political parties are exposed to. It is a problem that persists, despite the measures implemented through OLFPP 2007, such as increasing state funding or allowing the total or partial renegotiation of debts until this was completely prohibited in 2015 . The data must therefore serve to make political parties aware of the unfeasibility of continuing with this dynamic and the danger it poses for their survival in the future. Political parties should be the first in being made aware that they must change their attitude and take decisions to direct their action towards eliminating their shortcomings, and thus guaranteeing their economic sufficiency and therefore their independence.

However, one unexpected finding is that obtaining more income does not directly imply a reduction in bank indebtedness, but it may have the opposite effect depending on the type of income and if the party has governed the country. This fact leads us to one of the main conclusions of this study: the relationship between the funding of political parties and their bank indebtedness is more complex than it may seem a priori. According to these results, party bank indebtedness cannot be resolved simply by increasing resources, since political parties could raise their expenditure budget as they see their income grow, thereby maintaining their financial dependence.

Nevertheless, not all revenues have the same influence on the bank indebtedness of parties. Although private revenues are the least quantitatively important in the financial structure of Spanish parties and in some cases have an almost residual character, they have the greatest impact on the indebtedness of these organisations. After all, state funding is forced upon them on the basis of election results, so their capacity to raise private funding plays an important role in the need to resort to indebtedness with credit institutions. It is especially noteworthy that both public and private financing do not have the same impact on the bank indebtedness of all political parties and that there are substantial differences between the parties that govern and those that do not with regard to the effect of bank loans, contributions from public posts and membership fees.

These results would show that the financing system is ineffective, at least in terms of equal opportunities. Although OLFPP 2007 and its subsequent reforms have introduced mechanisms to control the economic activity of parties to monitor effective compliance with the regulations, and to avoid cronyism or any type of illegal practice, it has not undergone significant changes that focus on a new economic model of financing.

Instead, OLFPP 2007 has been limited to incremental reforms. After its approval, private revenues lost importance in party funding, as a consequence of the restriction of donations and the inability to encourage small private contributions. This has led to an increase in the disproportionality between private and public funding. A disproportion that would not be pernicious on its own if it were not for the fact that it does not guarantee economic sufficiency, equal opportunities or the establishment of links with civil society, as stated in the theoretical framework and evidenced by the results of the study. For all these reasons, this research shows the legislator that there is a need to design a funding regime that 
realistically promotes these three premises. In line with the central theme of our paper, this regime should guarantee economic sufficiency, and if it cannot prevent over-indebtedness of the organisations, it should limit it, so that they can exercise their institutional and social functions with total independence.

In this context, firstly, an effective expenditure restraint should be developed through a regulatory reform that provides incentives for parties to contain spending. This is a question of establishing measures that will enable the parties to balance their finances by adjusting their expenditure to their income. To this end, it would be necessary to carry out an exhaustive analysis of the political parties' expenditure items in order to design an optimisation plan for them.

Secondly, the likelihood of indebtedness of political parties must be limited. The income from bank loans and credits that a party may obtain annually should be limited and subordinate to the rest of the funding received. Of course, all indebtedness transactions with credit institutions must be subject to strict controls and maximum transparency so that the State and citizens are assured of compliance with the legislation, and the complete independence of the parties involved in the transaction is guaranteed. It is a question of introducing mechanisms that reduce the opportunities for behaviours that cause agency losses (Jiménez, 2014).

Thirdly, in order to continue to nurture democracy, minimum state funding is needed to provide basic guarantees of equal opportunities for all parliamentary and nonparliamentary democratic forces. However, excessive dependence on public resources must be avoided for two reasons. On the one hand, if bank indebtedness is conditioned, when the electoral results are not as expected, the financial burden increases, which has serious implications, as already mentioned. On the other hand, private resources need to be increased, as they are currently very scarce. It is essential to build links with civil society and for this reason, political parties should feel a need to empathise with citizens not just to obtain their votes but to also obtain their financial support. It is a partisan task that the parties would only be willing to do if they were forced to. Therefore, an appropriate measure in this regard would be to make state funding dependent on the private income they obtain in accordance with the limitations set out in the law. In this respect, however, the limits should be reconsidered, and the focus should be on proper monitoring and maximum transparency rather than on systematic prohibition.

And, fourthly, it has become clear that both the State and citizens must have greater power to control the income and expenditure of political parties. However, in order to achieve this, the parties should be required to provide greater transparency. Without total transparency, unlike the practices employed today, accountability does not prevent illicit practices, eliminate suspicions about political decisions that prioritize individual economic interests over general ones, nor does it generate public confidence in the political system and politicians.

To conclude, it should be remembered that the results of this study are limited to the period between 2000 and 2013. This means that neither the new Accounting Plan, adapted to political organisations, nor the OLFPP 2015, prohibiting debt forgiveness and introducing new limits and prohibitions on private financing, had come into force. In which case, it would be appropriate to carry out the same study in the future, once a sufficient number of annual accounts audited by the Court of Auditors are available. Also, an analysis should be made of the evolution of the parties and how these reg- ulatory changes affect this evolution, which a priori may be significant. Similarly, it would be very interesting to extrapolate this study to political parties in other European countries and make a comparison.

\section{Funding}

This research did not receive any specific grant from funding agencies in the public, commercial or not-for-profit sectors.

\section{Conflict of interests}

The authors declare no conflict of interests.

\section{References}

Álvarez Conde, E. (1994). Algunas propuestas sobre la financiación de los partidos políticos. In La financiación de los partidos políticos. Colección Cua odernos y Debates, 47, 13-36. Madrid: Centro de Estudios Constitucionales.

Álvarez Conde, E. (2005). El Derecho De Partidos. Madrid: Colex.

Argandoña, A. (2001). La financiación de los partidos políticos y la corrupción en las empresas. Papeles de Ética, Economía y Dirección, 6, 1-20.

Ariño, G. (2009). La financiación de los partidos políticos. Madrid: Ediciones Cinca.

Balaguer, M.T. \& Brun, M.I., (2013). El efecto del gasto público sobre las posibilidades de reelección de los gobiernos locales. Revista de Contabilidad - Spanish Accounting Review, 16 (1), 74-80. https://doi.org/10.1016/ S1138-4891(13)70008-6

Blanco Valdés, R. (1994). Consideraciones sobre la Necesaria Reforma del Sistema Español de Financiación de los Partidos Políticos en La Financiación de los Partidos Políticos: 37-52. Madrid: Centro de Estudios Constitucionales.

Blanco, R. (1995). La problemática de la financiación de los partidos políticos en España, Regulación jurídica y propuestas de reforma. Revista de Estudios Políticos, 87, 163197.

Bolleyer, N. (2009). Inside the Cartel Party: Party Organisation in Government and Opposition. Political Studies, 57(3), 559-79. https://doi.org/10.1111/j.1467-9248. 2008.00741.X

Brusca, I. \& Condor, V. (2001). El análisis financiero en las administraciones locales. Revista Es opañola de Financiación y Contabilidad, 30(108), 475-503. https:// www.jstor.org/stable/42781385

Casal Bértoa, F., Molenaar, F., Piccio, D.R. \& Rashkova, E.R. (2014). The World Upside Down: Delegitimising Political Finance Regulation. International Political Science Review, 35(3), 355-376. https://doi.org/10.1177/ 0192512114523302.

Casas Zamora, K. (2008). Political Finance and State Funding Systems: An Overview. Washington, DC: International Foundation for Electoral Systems.

Coello, J.M. (2012). La Ley Orgánica 5/2012, de 22 de octubre, una buena reforma en una buena dirección del régimen de financiación de los partidos polítiogos. Foro 
Nueva Época, 15(2), 337-344. https://doi.org//10.5209/ rev FORO.2012.v15.n2.41498.

Del Castillo, P. (1985). La financiación de partidos y candidatos en las democracias occidentales. Madrid: Centro de Investigaciones Sociológicas.

Del Castillo, P, (1994). La financiación Pública de los Partidos en España. Revista de Derecho Político, 22, 149-175.

Díaz Santana, H. (1998). Experiencia con el financiamiento de partidos políticos en España. En Valdés, S. (ed.), Reforma del Estado. Volumen I: Financiamiento Político (pp. 171-214). Santiago de Chile: Centro de Estudios Públicos.

DiMaggio, P.J. \& Powell, W.W. (1983). The iron cage revisited: Institutional isomorphism and collective rationality in organizational fields. American Sociological Review, 48(2), 147-160. https://doi.org/10.2307/2095101

Falguera, E. (2015). Conclusiones. In Falguera, E., Jones, S. y Ohman, M. (Eds.), El Financiamiento de los partidos políticos y las campañas electorales. Manual sobre financiamiento político (pp. 388-413). Estocolmo: IDEA International.

García Cotarelo, R. (1985). Los Partidos Políticos. Madrid: Sistema.

García Sánchez, I.M., Prado Lorenzo, J.M. \& Cuadrado Ballesteros, B. (2011). Do progressive governments undertake different debt burdens? Partisan vs. electoral cycles. Revista de Contabilidad -Spanish Accounting Review, 14(1), 29-57. https://doi.org/10.1016/ S1138-4891(11)70021-8

García Viñuela, E., \& Vázquez, P. (1996). La financiación de los partidos políticos: un enfoque de elección pública. Revista de Estudios Políticos, 92, 281-296.

García Viñuela, E. \& Artés, J. (2005). El gasto público en financiación política. Las subvenciones para el gasto ordinario de los partidos. Revista de Estudios Políticos, 128, 255-291.

García Viñuela, E. (2007). La Regulación del Dinero Público. Revista Española de Investigaciones Sociológicas, 118, 6595.

García Viñuela, E. (2009). Financiación pública de los partidos y cartelización de la oferta política. Revista Española de Ciencia Política, 20, 75-96.

García Viñuela, E. \& González de Aguilar, C. (2011). Regulación al servicio de los reguladores: la ley de financiación de los partidos políticos de 2007. Comunicación presentada en XVIII Encuentro de Economía Pública: "Economía Pública: reflexiones para después de la crisis", Málaga, España.

García Viñuela, E. \& González de Aguilar, C. (2014). Financiación de los partidos y búsqueda de rentas, un análisis de las reformas de la financiación política española de 2007 y 2012. Revista Española de Ciencia Política, 34, 145-165.

Gillespie, R. (1998). Party Funding in a New Democracy, Spain. In Burnell, P. \& Ware, A. (Eds.), Funding Democratization (pp. 73-93). Manchester: Manchester University Press.

Gujarati, N. (2004). Basic Econometric. New York: The McGraw-Hill Companies.

Gray, C. \& Kaufman, D. (1998). Corruption and Development. Finance and Development, 35, 7-10.

GRECO. (2009). Third Evaluation Round. Evaluation Report on Spain on Transparency of Party Funding (Theme II). Retrieved from: https: //rm.coe.int/CoERMPublicCommonSearchServices/
DisplayDCTMContent?documentId= $09000016806 c 9 d 72$.

GRECO. (2011). Third Evaluation Round. Group of States against Corruption Compliance Report on Spain on Transparency of Party Funding. Retrieved from: https: //rm.coe.int/CoERMPublicCommonSearchServices/ DisplayDCTMContent?documentId= 09000016806c9daf.

GRECO. (2013). Third Evaluation Round. Group of States against Corruption Second Compliance Report on Spain on Transparency of Party Funding. Retrieved from: https: //rm.coe.int/CoERMPublicCommonSearchServices/ DisplayDCTMContent?docudocume= 09000016806c9db2.

GRECO. (2015). Third Evaluation Round. Group of States against Corruption Second Addendum to the Second Compliance Report on Spain on Transparency of Party Funding. Retrieved from: https: //rm.coe.int/CoERMPublicCommonSearchServices/ DisplayDCTMContent?documentId= 09000016806 cac21.

Greene, W.H. (1998). Análisis Econométrico. Madrid: Prentice-Hall.

Hausman, J.A. (1978). Specification test in econometrics. Econometrica, 46, 1251-1271. https://doi.org/10.2307/ 1913827

Hausman, J. \& McFadden, C. (1984). Specification Tests for the Multinomial Logit Model. Econometrica, 52, 12191240. https://doi.org/10.2307/1910997

Holgado, M. (2003). La financiación de los partidos políticos en España. Valencia: Tirant lo Blanch.

Jiménez, F. \& Villoria, M. (2018). Party funding in Spain. In Mendilow, J. \& Phélippeau, E. (Eds.) Handbook of political party funding (pp. 349-364). Cheltenham: Edward Elgar Publising Limited.

Jiménez, F. (2014). La trampa política: la corrupción como problema de acción colectiva. En Pastor, E., Tamez, G. \& Sáenz K. (Eds.) Gobernabilidad, ciudadanía y democracia participativa. Análisis comparado España-México (pp. 157-174). Madrid: Dykinson.

Johnston, M. (1999). Corruption and Democratic Consolidation [Paper]. Conference on Democracy and Corruption, Shelby Cullom Davis Center for Historical Studies, Princeton University.

Johnston, M. (2005). Political parties and democracy in theoretical and practical perspectives: Political finance policy, parties, and democratic development. Washington, DC: National Democratic Institute for International Affairs.

Katz, R. \& Mair, P. (1995). Changing Models of Party Organization and Party Democracy: The Emergence of the Cartel Party. Party Politics, 1(1), 5-28. Party Politics, 1(1), 5-28. https://doi.org/10.1177/1354068895001001001

Kleinbaum, D.G., Kupper, L.L., Muller, K.E. \& Nizam, A. (1998). The Method of Maximum Likelihood. Applied Regression Analysis and Other Multivariable Methods. Pacific Grove, CA: Duxbury Press.

López Garrido, D. (1994). La Financiación de los Partidos Políticos: Diez Propuestas de Reforma. In La Financiación de los Partidos Políticos (pp. 65-72). Madrid: Centro de Estudios Constitucionales.

Lupia, A. (2003). Delegation and its Perils. In Strom, K., Mueller, W. \& Bergman, T. (Eds) Delegation and Accountability in Parliamentary Democracies (pp. 33-54). Oxford: Oxford University Press.

Maroto, M. (2012). Corrupción y financiación de partidos 
políticos, Un análisis político-criminal. [PhD Thesis]. University of Castilla-La Mancha, Spain.

Maroto, M., Anderica, V., Baleato, S. \& Ongil, M. (2013). Qué hacemos con la financiación de los partidos. Madrid: Akal.

Maroto, M. (2017). Treinta años después de la primera ley orgánica de financiación de partidos políticos (1987-2017): ¿hacia un cambio de ciclo? Informe sobre la democracia en España 2017. Madrid: Fundación Alternativas.

Maroto, M. (2018). Una democracia nada perfecta, continuidades en la financiación de los partidos españoles desde la transición política a nuestros días. Hispania Nova, 16, 685-710. https://doi.org/10.20318/hn.2018.4052

Martínez Cousinou, G. (2013). El control de la corrupción política en el ámbito de la financiación de los partidos, actores, intereses y estrategias en España y Reino Unido. [PhD Thesis]. National University of Distance Education, Spain.

Martínez Cuevas, M. D. (2006). El Régimen Jurídico de los Partidos Políticos. Madrid: Marcial Pons.

Menard, S. (2002). Applied logistic regression analysis. Series: quantitative applications in the social sciences. Londres: Sage Publications.

Nassmacher, K.H. (2001). Foundations for Democracy, Approaches to Comparative Political Finance. Baden-Baden: Nomos.

Nassmacher, K.Z. (2003). Introduction: Political Parties, Funding and Democracy. In Austin, R. \& Tjernström, M. (Eds), Handbook Series Funding of Political Parties and Election Campaigns (pp. 1-19). Estocolmo: IDEA International.

Núñez, M. (2009). La financiación de los partidos políticos. Revista Española de Control Externo, 33, 163-174.

Ohman, M (2013). Controlling money in politics: An Introduction. Washington: International Foundation for Electoral Systems.

Pajares, E. (1998). La financiación de las elecciones. Madrid: Congreso de los Diputados.

Pajares, E. (2016). La financiación de los partidos políticos. Eunomía, 11, 176-210. http://dx.doi.org/10.20318/ eunomia.2016.3287.

Palomares, J. \& Peset, M.J. (2015). Estados financieros, interpretación y análisis. Madrid: Ediciones Pirámide.

Paltiel, K.Z. (1980). Public financing abroad, contrasts and effects. In Parties, Interest Groups and Campaign Finance Laws, 70-354. Washington, DC: American Enterprise. Institute.

Pedhazur, E. (1997). Multiple Regression in Behavioral Research. Fort Worth: Hartcourt Brace College Publishers.

Pelizzo, R. (2004). From Principle to Practice: Constitutional Principles and the Transformation of Party Finance in Germany and Italy. Comparative European Politics, 2(2), 123-141. https://doi.org/10.1057/palgrave.cep. 6110032

Pérez Francesch, J.L. (2009). La financiación de los partidos políticos en España, Consideraciones a partir de los informes del Tribunal de Cuentas y de la nueva ley orgánica $8 / 2007$, de 4 de julio. Papers. Revista de Sociología, 92, 249-271. https://doi.org/10.5565/rev/papers/ v92n0.716

Pérez Ugena, M. (2015). El papel actual de los partidos políticos. Consecuencias para el modelo de financiación. Teoría y Realidad Constitucional, 35, 383-411.

Pinto-Duschinsky, M. (2002). Financing Politics: A Global View. Journal of Democracy, 13(4), 69-86. https://doi. org/10.1353/jod.2002.0074.

Pinto-Duschinsky, M. (2008). Paying for the Party: Myths and Realities in British Political Finance. London: Policy Exchange.

Prpi, I. (2004). Rije unaprijed. In Prpi, I. (ed.), Drava i politike stranke, (pp. 7-20) Zagreb: Narodne novine \& Hrvatski pravni centar.

Rodríguez López, A. (2011). Contabilidad y financiación de los partidos políticos. Valencia: CISS.

Rodríguez López, A. \& Fidalgo, E. (2011). El endeudamiento en la política. Análisis contable de los recursos financieros exigibles de los partidos. Partida Doble, 233, 10-19.

Rodríguez Teruel, J., Baras, M., Barberà, O., \& Barrio, A. (2013). Financiación de los partidos y transparencia democrática. Buenas prácticas en Europa y América del Norte. Barcelona: Fundació Catalunya Europa.

Rodríguez Teruel, J. (2016). Dinero público y ciudadanos ausentes, la financiación de los partidos políticos en España. In, FJ Llera (Eds.) Desafección política y regeneración democrática en la España actual, 135-172. Madrid: Centro de Estudios Políticos y Constitucionales.

Rodríguez Teruel, J. \& Casal Bértoa, F. (2016). La financiación pública de los partidos políticos, España en perspectiva comparada. Presupuesto y Gasto Público, 82, 159. 178.

Rodríguez Teruel, J. \& Casal Bértoa, F. (2018). Cuarenta años de financiación de partidos políticos en España. In, [España constitucional (1978-2018)][]: trayectorias y perspectivas Vol. 4, Tomo 4, 3269-3286. Madrid: Centro de Estudios Políticos y Constitucionales.

Rose Ackerman, Susan (1996). The Political Consequences of Corruption. Causes and Consequences. World Bank, Note 74

Ruiz Rico, G. (2015). El control sobre la financiación de los partidos políticos, un desafío permanente para el legislador. Teoría y Realidad Constitucional, 35, 281-308.

Sánchez Muñoz, O. (2013). La financiación de los partidos políticos en España, ideas para un debate. Revista Española de Derecho Constitucional, 99, 161-200.

Sánchez Muñoz, O. (2015). La insuficiente reforma de la financiación de los partidos, la necesidad de un cambio de modelo. Revista Española de Derecho Constitucional, 104, 49-82.

Sakia, R. M. (1992). The Box-Cox transformation technique: A review. The Statistician, 41, 169-178. https://doi.org/ $10.2307 / 2348250$

Santano, A.C. (2016). La financiación de los partidos políticos en España. Madrid: Centro de Estudios Políticos y Constitucionales.

Sartori, G. (2000). Partidos y Sistemas de Partidos. Madrid: Alianza Editorial.

Scarrow, S. (2006). Party Subsidies and the Freezing of Party Competition, Do Cartel Mechanisms Work? West European Politics, 29(4), 619-639. https://doi.org/10. $1080 / 01402380600842148$.

Seligson, M.A. (2002). The Impact of Corruption on Regime Legitimacy: A Comparative Study of Four Latin American Countries. The Journal of Politics, 64(2), 408-433. https: //doi.org/10.1111/1468-2508.00132

Tanzi, V. \& Davoodi, H. (1997), Corruption, Public Investment and Growth. International Monetary Fund. Working Paper.

Tukey, J.W. (1977). Exploratory Data Analysis. Reading, Massachusetts: Addison-Wesley.

Van Biezen, I. (2000). Party Financing in New Democracies, Spain and Portugal. Party politics, 6(3), 701-722. https: 
//doi.org/10.1177/1354068800006003004

Van Biezen, I. (2003). Financing political parties and election campaigns-guidelines. Strasbourg: Council of Europe Publishing.

Van Biezen, I. (2004). Political parties as public utilities. Party politics, 10(6), 329-342. https://doi.org/10.1177/ 1354068804046914.

Van Biezen I. (2008). State intervention in arty politics: the public funding and regulation of political parties. European Review, 16(03), 337-353. https://doi.org/10. 1017/S106279870800029X.

Zovatto, D. (2006). Dinero y política en América Latina. Revista de Derecho Electoral, 2, 1-37. 